\title{
The response of selected members of the archaea to the Gram stain
}

\author{
Terry J. Beveridge and Susanne Schultze-Lam \\ Author for correspondence: Terry J. Beveridge. Tel: +1 5198244120 ext. 3366. Fax: +1 5198371802 . \\ e-mail: tjb@micro.uoguelph.ca
}

Department of

Microbiology, College of

Biological Science,

University of Guelph,

Guelph, Ontario, Canada

N1G 2W1

\begin{abstract}
Archaea possess a broader range of cell envelope structural formats than eubacteria and their cell walls do not contain peptidoglycan. Some archaea have only a single S-layer as their cell wall (e.g. Methanococcus jannaschii and Sulfolobus acidocaldarius), whereas others have multiple layers (e.g. Methanospirillum hungatei). Sometimes there can also be a high proportion of tetraether lipids in membranes to make the envelope more resilient to environmental stress (e.g. Methanococcus jannaschii and Sulfolobus acidocaldarius grown at $70^{\circ} \mathrm{C}$ ). Since the Gram reaction depends on both the structural format and the chemical composition of the cell envelope of eubacteria, it was important to determine if the same is true for archaea. Methanospirillum hungatei, Methanosarcina mazei, Methanobacterium formicicum, Methanococcus jannaschii and Sulfolobus acidocaldarius, chosen because of their different envelope formats and chemistries, were subjected to a Gram stain that can be used for transmission electron microscopy. In this staining regimen, the iodine is replaced by potassium trichloro $\left(\eta^{2}-\right.$ ethylene)platinate(II) as the mordant, and the platinum of the new compound is the electron-scattering agent for electron microscopy. Of all these archaea, only Methanobacterium formicicum stained Gram-positive since its pseudomurein wall remained intact; the platinum compound formed large electron-dense aggregates with the crystal violet that were located in the vicinity of the cell wall and the plasma membrane. All but the terminal filament cells of Methanospirillum hungatei stained Gram-negative because the limiting porosity of its external sheath was so small that the Gram reagents could not enter the cells. The terminal cells of filaments stained Gram-positive because the staining reagents gained entry through the terminal plugs. All other archaea stained Gram-negative because their cell walls were so disrupted during staining that the crystal violet-platinum complex could not be retained by the cells. Methanococcus jannaschii was grown at both $50^{\circ} \mathrm{C}$ and $70^{\circ} \mathrm{C}$ so that the tetraether lipids in its plasma membrane could be increased from $20 \%\left(50^{\circ} \mathrm{C}\right)$ to $45 \%\left(70^{\circ} \mathrm{C}\right)$ of the total lipids; in both cases the cells stained Gram-negative.
\end{abstract}

Keywords: archaea, Gram stain, walls, cell envelopes, ultrastructure

\section{INTRODUCTION}

Microbiologists rely on the Gram stain for the initial screening of new isolates so that they can be classified as either Gram-positive or Gram-negative. Since the turn of

Abbreviations: EDS, energy-dispersive X-ray spectroscopy; LM, light microscopy; TEM, transmission electron microscopy; TPt, trichloro $\left(\eta^{2}-\right.$ ethylene)platinate. the century, the correlation between Gram stain and structural detail of cell envelopes has been derived from years of experience by many microbiologists but is based, primarily, on eubacteria. Traditionally this has meant that Gram-negative bacteria possessed a bilayered outer membrane, a thin peptidoglycan layer and a bilayered plasma membrane (such as found in Escherichia coli) as their essential structural elements for a cell envelope (Beveridge, 1981; Beveridge \& Graham, 1991). Gram-positive 
bacteria (such as Bacillus subtilis) possessed thick amorphous cell walls overlying the plasma membrane (Beveridge, 1981), although more recent work using cryo-electron microscopy has now shown these envelopes to be more complex (Beveridge \& Graham, 1991; Graham \& Beveridge, 1994). The staining response for eubacteria has usually been clear-cut with few exceptions (Beveridge \& Davies, 1983; Beveridge, 1990).

Surprisingly, little work has been done on the archaea and their response to the Gram stain. Most representatives of this relatively recently recognized Domain stain Gramnegative, but the rationale for this is still unclear. Since the structural formats of archaeal cell envelopes are dramatically different from those of eubacterial envelopes and because their chemical makeup also differs (Beveridge, 1988; König, 1988; Beveridge \& Graham, 1991), it is important to determine whether or not the Gram reaction of archaea relies on the properties of the cell envelope as it does for eubacteria.

In 1983, we performed a detailed study to elucidate the chemical mechanism of the Gram stain in E. coli and $B$. subtilis as representative Gram-negative and Gram-positive bacteria (Davies et al., 1983). During this study, we determined that the iodide of Gram's iodine solution complexes with crystal violet via a metathetical anion exchange with chloride, forming a more neutral charge transfer complex with the pi bonds of the dye. As a result, the crystal violet-iodide complex precipitates from solution to form large purple aggregates within the bacterial cell. In E. coli, since ethanol decolorization dissolves the outer and plasma membranes, these stain aggregates are liberated and the cell becomes Gram-negative (Beveridge \& Davies, 1983). Ethanol does not dissolve the thick cell wall of $B$. subtilis, the stain aggregates remain within the cell, and these cells stain Gram-positive (Beveridge \& Davies, 1983). Knowing the chemical mechanism behind the Gram stain, we were able to design and synthesize a new mordant, potassium trichloro $\left(\eta^{2}\right.$-ethylene $)$ platinate(II) ('TPt), to replace the iodide of Gram's iodine solution (Davies et al., 1983). TPt is electron-dense, so the exact location of the staining aggregates could be visualized by transmission electron microscopy (TEM) and the platinum within the aggregates could be identified by energy-dispersive $\mathrm{X}$-ray spectroscopy (EDS) within individual cells (Beveridge \& Davies, 1983; Beveridge, 1990). TPt is now commercially available through the Aldrich Chemical Company. In the work described here, this technique was used to determine the mechanism of the Gram reaction on a number of archaea. These were selected on the basis of their cell envelope formats, wall chemistry, and tetraether lipid constitution, and are representative members possessing the unique surfaces that exist in the archaea.

\section{METHODS}

Bacteria and growth conditions. Methanospirillum bungatei GP1 (DSM 1101) was grown at $35^{\circ} \mathrm{C}$ under an atmosphere of $\mathrm{H}_{2} / \mathrm{CO}_{2}(80: 20, \mathrm{v} / \mathrm{v})$ in mineral salts medium SA (Breuil \& Patel, 1980) supplemented with $5 \mu \mathrm{M} \mathrm{NiCl}$. Methanococcus jannascbii JAL-1 (DSM 2661) was grown in defined medium under the same $\mathrm{H}_{2} / \mathrm{CO}_{2}$ atmosphere at either $50^{\circ} \mathrm{C}$ or $70^{\circ} \mathrm{C}$ as described by Ferrante et al. (1990). Methanobacterium formicicum was grown in the medium described by May et al. 1988). Methanosarcina mazei S6 (DSM 2053) was grown at $35^{\circ} \mathrm{C}$ on methanol $(0.6 \%, \mathrm{v} / \mathrm{v})$ under $\mathrm{N}_{2}$ in Balch medium no. 3 in which the yeast extract and tryptone were replaced by $0.1 \mathrm{~g}$ L-isoleucine $1^{-1}$ and 0.05 g L-leucine $1^{-1}$, the $\mathrm{NH}_{4} \mathrm{Cl}$ concentration was raised to $0.54 \mathrm{~g} \mathrm{l}^{-1}$, and $\mathrm{Na}_{2} \mathrm{CO}_{3}$ was replaced by $\mathrm{NaHCO}_{3}$. Sulfolobus acidocaldarius 98-3 (ATCC 33909) was grown under aerobic conditions at $70^{\circ} \mathrm{C}$ using the medium described by Brock $e t$ al. (1972).

Gram stain, light microscopy (LM), TEM and EDS. Once cells had achieved the mid-exponential growth phase (usually $\mathrm{OD}_{600}$ $0.3-0.5$; path length $1 \mathrm{~cm}$ ), they were harvested by centrifugation and processed by both the conventional and modified Gram stain regimens as outlined by Davies $e t$ al. (1983). TPt was obtained from Aldrich; it was used in all experiments after being compared to our own stock of chemically synthesized TPt (Chock et al., 1973; Davies et al., 1983) and found to be satisfactory.

LM was used on all samples to ensure that the staining response was accurate. As eubacterial controls, B. subtilis or Streptococcus pyogenes (Gram-positives) and E. coli (Gram-negative) were also processed for comparison with the archaea. Stains for LM were done on heat-fixed smears of bacteria according to the following procedure. Crystal violet was used to flood the smear for $60 \mathrm{~s}$, followed by flooding with an equal volume of Gram's iodine solution (conventional Gram procedure) or $50 \mathrm{mM}$ TPt (TPtmodified procedure) for an additional $60 \mathrm{~s}$. The mordanted stain was gently washed under running tap water $\left(\sim 4{ }^{\circ} \mathrm{C}\right)$ and blotted dry with absorbent filter paper. The smears were decolorized in a slow, steady stream of hydrous $95 \%(\mathrm{v} / \mathrm{v})$ ethanol for $30 \mathrm{~s}$ and were then washed with water, blotted dry, and counter-stained with carbol fuchsin for $60 \mathrm{~s}$. The smears were then washed with water, blotted dry, and observed by LM. For electron microscopy and EDS, cells were harvested by centrifugation and washed three times in $25 \mathrm{ml} 50 \mathrm{mM}$ HEPES buffer ( $\mathrm{pH} \mathrm{6.8)} \mathrm{containing} 1 \mathrm{mM} \mathrm{MgCl}_{2}$. They were then put through either the conventional or the TPt-modified Gram procedure as outlined above. More detail can be found in Fig. 1 of Davies et al. (1983). The cells were then re-equilibrated to $50 \mathrm{mM}$ HEPES buffer, fixed for $1 \mathrm{~h}$ in $5 \%(\mathrm{v} / \mathrm{v})$ glutaraldehyde in buffer, washed (without heavy-metal staining), and processed into Epon 812 (CanEM, Guelph, Canada). For added contrast to decipher cellular structure after EDS analysis, some sections were stained with uranyl acetate and lead citrate as outlined by Beveridge \& Davies (1983).

EDS was performed on unstained thin sections, using the spectrum from the embedding resin as an index of specimen background radiation. $\mathrm{Pt}\left(\mathrm{M}_{\alpha, \beta}\right.$ and $\left.\mathrm{L}_{\alpha, \beta}\right)$ lines were monitored for the Gram precipitate (the TPt-crystal violet complex). Spectral lines slightly upstream and downstream in the X-ray spectrum were used to establish readings of the continuum to ensure the validity of the $\mathrm{Pt}$ readings. Point analyses were performed using a Philips EM400T equipped with a Link LZ-5 detector and a Link exl processor for EDS at $100 \mathrm{kV}$, using a spot size of $2 \cdot 0-20 \cdot 0 \mathrm{~nm}$ and an emission current of $80 \mu \mathrm{A}$. Counting times of $100-200 \mathrm{~s}$ (live time) were typically used.

\section{RESULTS}

Table 1 shows the results of the analyses of the archaea by LM, TEM and EDS; Figs $1-4$ provide representative images on which Table 1 is based. Fig. 5 shows the typical 


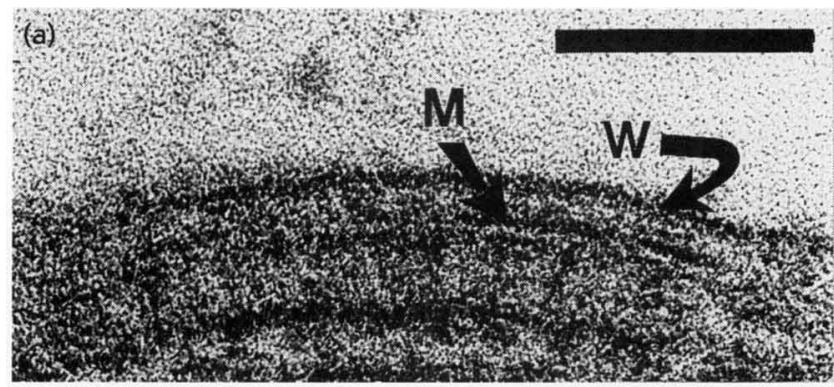

TEM-EDS results for a control Gram-positive eubacterium (Streptococcus pyogenes).

The archaea used for our study were carefully chosen so that they represented the diverse number of cell envelopes that exist in this Domain. These can be very simple (i.e. the cell wall can consist of a single S-layer as in Sulfolobus acidocaldarius and Methanococcus jannaschii) or they can be amongst the most complex of all prokaryotes (i.e. the multiple layers in Methanospirillum bungatei). Fig. 1 shows the cell envelope formats that our archaea possessed.

(b)
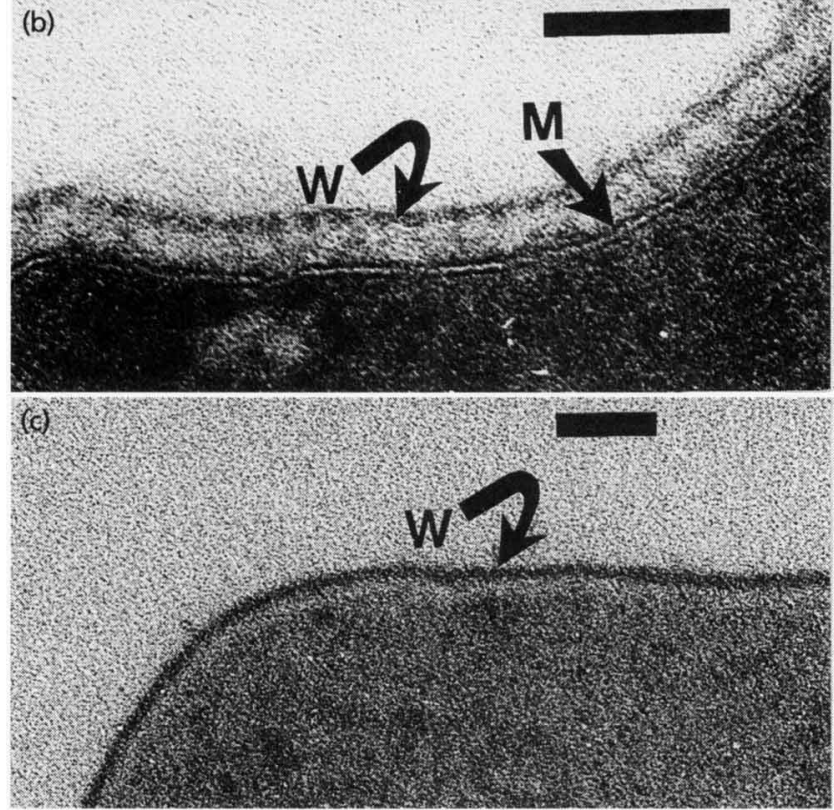

(d)
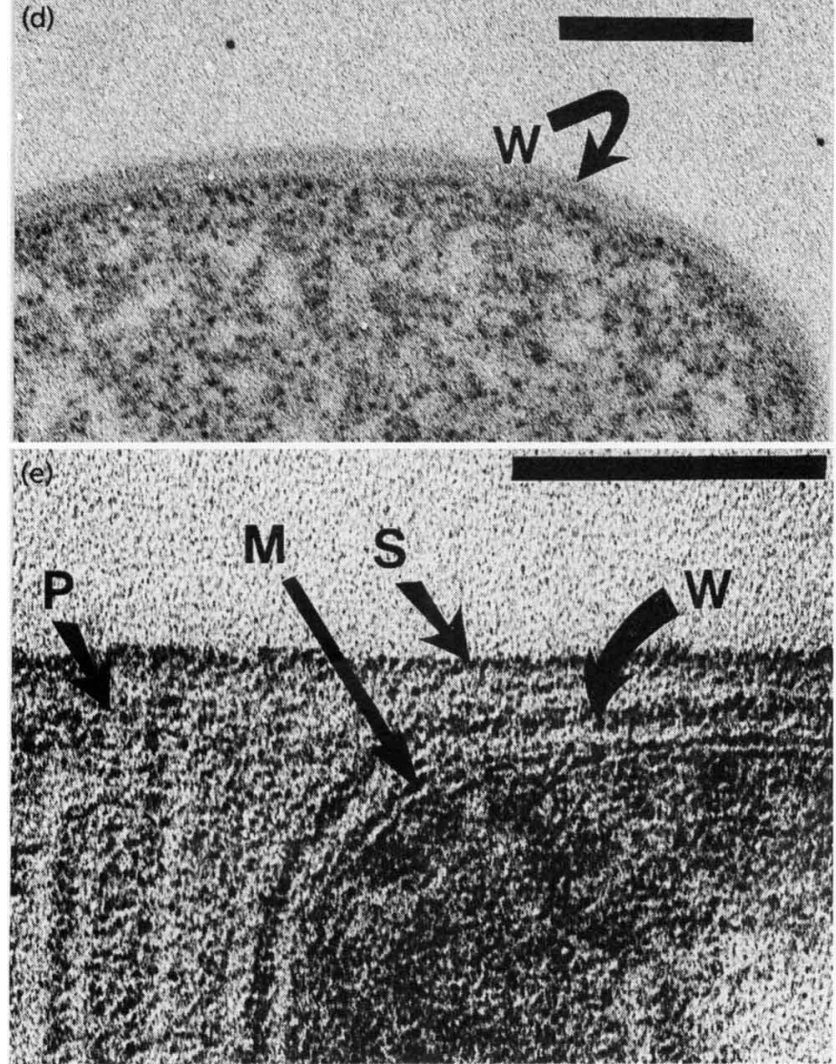
Methanococcus jannaschii (Fig. 1a) and Sulfolobus acidocaldarius (Fig. 1b) had the simplest envelopes, consisting of a plasma membrane and a single proteinaceous (Metbanococcus jannaschii) or glycoproteinaceous (Sulfolobus acidocaldarius) S-layer. There was no change in the envelope profile of Methanococcus jannaschii when it was grown at either $50^{\circ} \mathrm{C}$ or $70^{\circ} \mathrm{C}$. Methanobacterium formicicum did not possess an $\mathrm{S}$-layer, but it had a relatively thick $(\sim 15 \mathrm{~nm})$ amorphous wall (Fig. 1c) composed of pseudomurein (Kandler \& König, 1985; König, 1988), whereas Methanosarcina mazei possessed a wall of variable thickness (15-30 nm; Fig. 1d) composed of amorphous methanochondroitin (Kandler \& König, 1985; König, 1988) which overlies a single S-layer (Aldrich et al., 1986). This S-layer was not seen in any of our thin sections (Fig. 1d) even when aligned correctly at right angles to the electron beam or when tilting experiments were performed. The most complex envelope profile was that of Methanospirillum bungatei, which consisted of an S-layered sheath (Stewart et al., 1985), an S-layered wall (Firtel et al., 1993), and a multilayered cell spacer (Firtel et al., 1994) that separated the cells from one another within a filament (Fig. 1e; see Beveridge et al., 1987, for more structural details).

\section{Light microscopy (LM)}

When the cells were subjected to either the conventional regimen or the TPt regimen of the Gram stain, LM showed most of the archaea to be Gram-negative (Table 1) when compared to the eubacterial controls. The two staining regimens were indistinguishable from one another on all bacteria. It was our impression that Methanococcus jannaschii (at both growth temperatures), Sulfolobus acidocaldarius and Methanosarcina mazei did not have the same colour intensity (as Gram-negatives) as our eubacterial $E$. coli control had when we viewed the samples by LM. Light micrographs of these stains, after the unstained backgrounds of each were adjusted to similar intensities, confirmed our visual evaluation (data not shown). Presumably, this was an indication of the

Fig. 1. Thin sections of cell envelopes of the archaea used in this study. (a) Methanococcus jannaschii grown at $70^{\circ} \mathrm{C}$, (b) Sulfolobus acidocaldarius, (c) Methanobacterium formicicum, (d) Methanosarcina mazei, (e) Methanospirillum hungatei . W, wall; $M$, plasma membrane; $S$, sheath; $P$, spacer plug. The wall in (a), (b) and (e) is an S-layer. All sections are stained with uranyl acetate and lead citrate to heighten contrast. Bars, $100 \mathrm{~nm}$. 
Table 1. Description of the selected archaea and the results of the Gram stain as seen by LM, TEM and EDS

\begin{tabular}{|c|c|c|c|}
\hline \multirow[t]{2}{*}{ Bacterium } & \multirow[t]{2}{*}{ Cell envelope structure* } & \multicolumn{2}{|c|}{ Gram reaction } \\
\hline & & $\mathbf{L M}$ & TEM/EDS \\
\hline Sulfolobus acidocaldarius & $\begin{array}{l}\text { Single S-layer; plasma membrane with high } \\
\text { concentrations of tetraether lipids }\end{array}$ & Gram-negative & Cells lysed; no TPt \\
\hline \multicolumn{4}{|l|}{ Metbanococcus jannascbii } \\
\hline At $50^{\circ} \mathrm{C}$ & $\begin{array}{l}\text { Single S-layer; plasma membrane with low } \\
\text { amounts of tetraether lipids }\end{array}$ & Gram-negative & Cells lysed; no TPt \\
\hline At $70^{\circ} \mathrm{C}$ & $\begin{array}{l}\text { As above, with high amounts of tetraether } \\
\text { lipids }\end{array}$ & Gram-negative & Cells lysed; no TPt \\
\hline $\begin{array}{l}\text { Methanobacterium } \\
\text { formicicum }\end{array}$ & $\begin{array}{l}\text { Amorphous cell wall of pseudomurein; } \\
\text { plasma membrane with intermediate } \\
\text { amounts of tetraether lipids }\end{array}$ & Gram-positive & $\begin{array}{l}\text { Cells intact; } \mathrm{TPt} \\
\text { associated with cell wall } \\
\text { and plasma membrane }\end{array}$ \\
\hline Methanosarcina mazei & $\begin{array}{l}\text { Amorphous cell wall of methanochondroitin } \\
\text { over top of a single S-layer; few tetraether } \\
\text { lipids in plasma membrane }\end{array}$ & Gram-negative & Cells lysed; no TPt \\
\hline Methanospirillum bungatei & $\begin{array}{l}\text { S-layered sheath overlying a single S-layered } \\
\text { wall; multilayered spacer plugs between } \\
\text { cells; intermediate amounts of tetraether } \\
\text { lipids in plasma membrane }\end{array}$ & $\begin{array}{l}\text { Gram-negative except for } \\
\text { the terminal cells of each } \\
\text { filament, which were } \\
\text { Gram-positive }\end{array}$ & $\begin{array}{l}\text { Cells intact; TPt found } \\
\text { only in terminal cells of } \\
\text { each filament }\end{array}$ \\
\hline
\end{tabular}

* For details of cell envelope profiles and composition see Sprott et al. (1983, 1991), Kandler \& König (1985), Langworthy (1985), Stewart et al. (1985), Aldrich et al. (1986), Beveridge et al. (1993) and Firtel et al. (1993, 1994).

amount of carbol fuchsin (red) which complexed to the cells as a counterstain; all three archaea complexed less counterstain than E. coli.

Methanobacterium formicicum stained Gram-positive (Table 1 ); yet, when compared to Streptococcus pyogenes or $B$. subtilis as eubacterial controls, it was apparent that Methanobacterium formicicum's staining intensity was less than that of the two eubacteria (compare Fig. 2a and b).
Methanobacterium formicicum's colour was definitely purple and the cells were stained darker than E. coli (compare Fig. $2 b$ and $c$ ) but it was not as dark as that of $B$. subtilis (Fig. 2a). The difference in staining intensity between Metbanobacterium formicicum and $B$. subtilis could have simply been due to the narrower cell diameter of the former, but $S$. pyogenes (as another Gram-positive eubacterium), which has a similar cell diameter to Methanobacterium formicicum, was also more intensely stained. In
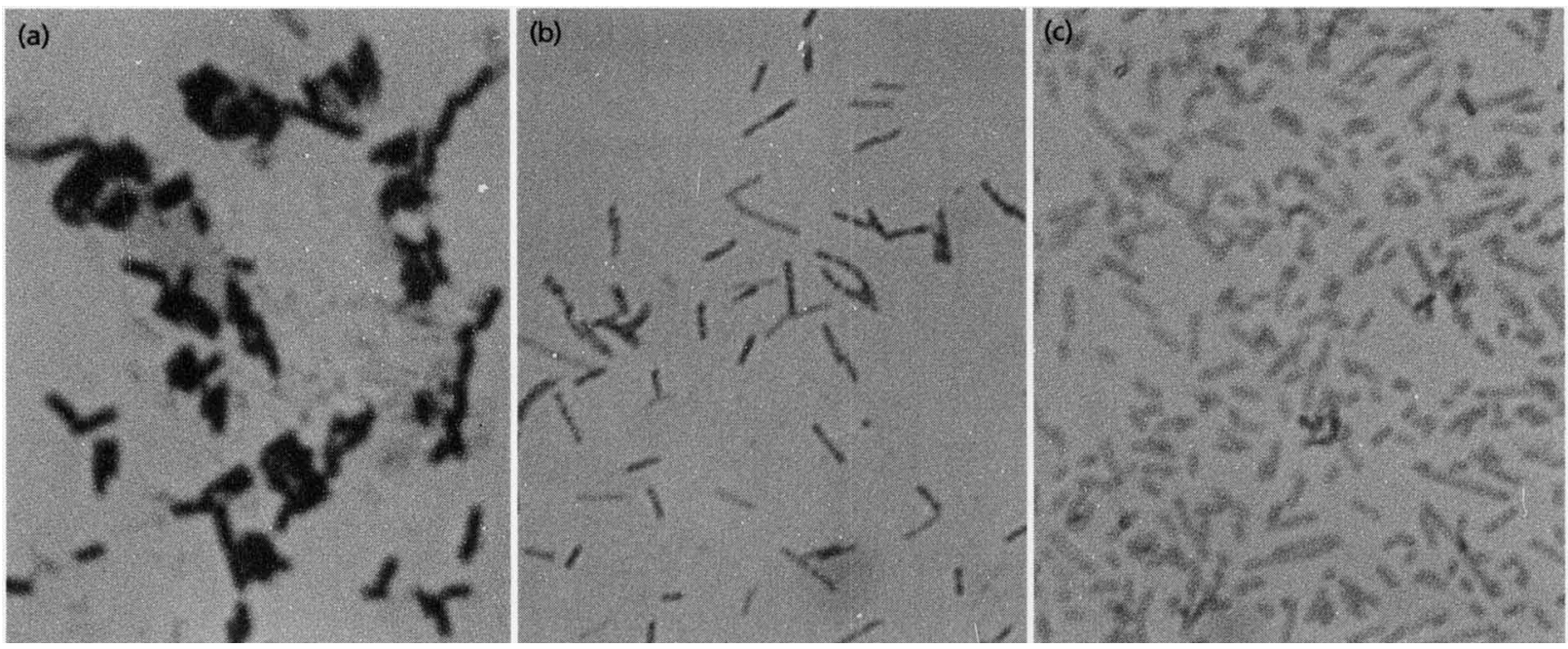

Fig 2. Gray-tone light micrographs of Gram-stained bacteria showing the different stain intensities. B. subtilis stained deep purple (a), Methanobacterium formicicum was lighter purple (b), and $E$. coli was deep red (c). All micrographs are the same magnification and the cell diameter of $E$. coli is $0.5 \mu \mathrm{m}$. 

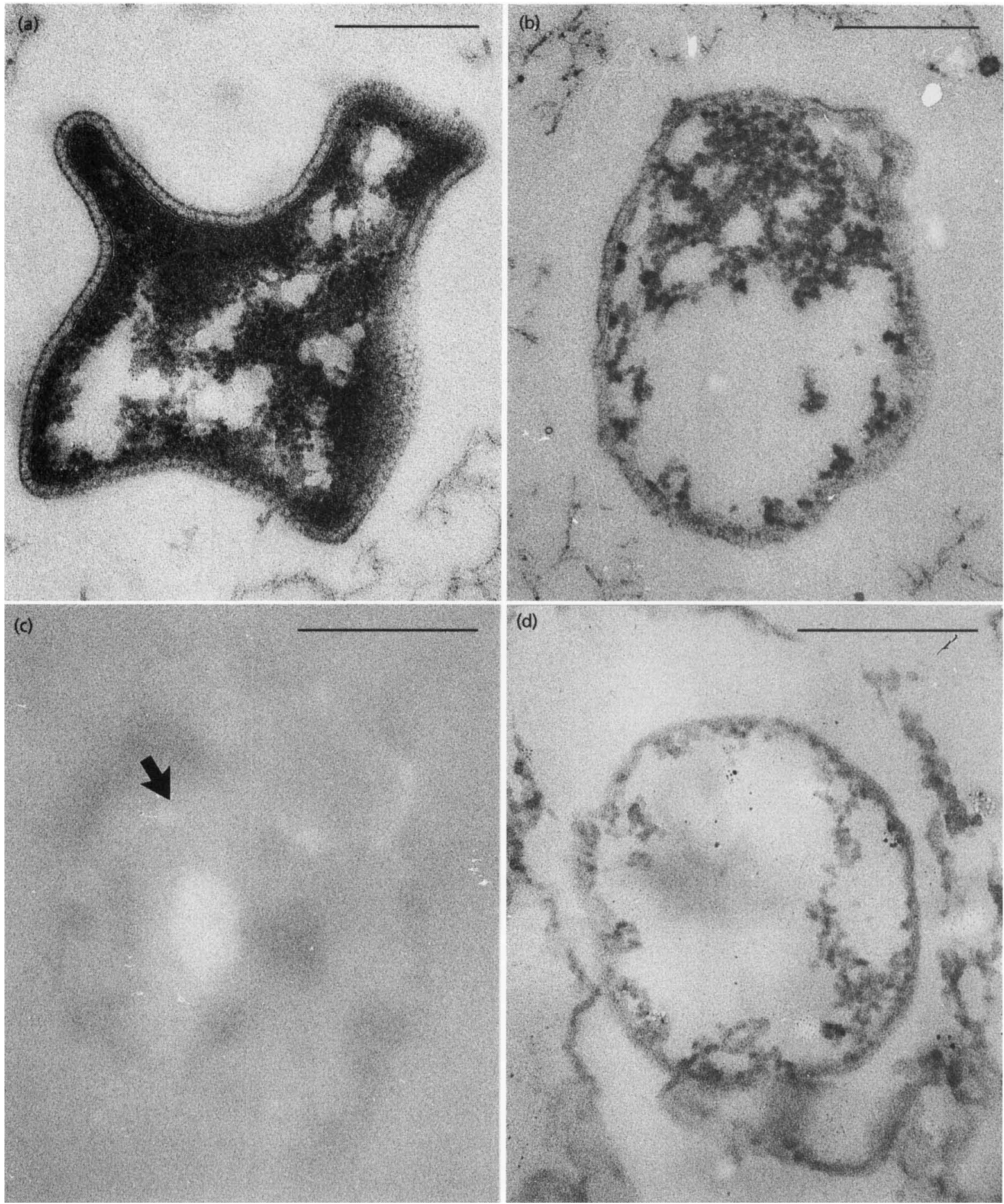

Fig. 3. Thin sections of single S-layered archaea before and after the Gram stain. (a, b) Sulfolobus acidocaldarius before (a) and after (b) the Gram reaction. Both of these sections are stained by heavy metal salts to heighten contrast and to show that most of the cellular substance has been lost during the reaction. The unstained section of Sulfolobus acidocaldarius shows that there are no electron-dense TPt-crystal violet aggregates in the cell, which was confirmed by EDS (c; arrow points to cellular substance within a lysed cell). Panel (d) is a heavy-metal-contrasted section of Methanococcus jannaschii (grown at $70^{\circ} \mathrm{C}$ ) and demonstrates that there is also little cellular substance in this cell after Gram staining. Bars, $0.5 \mu \mathrm{m}$. 

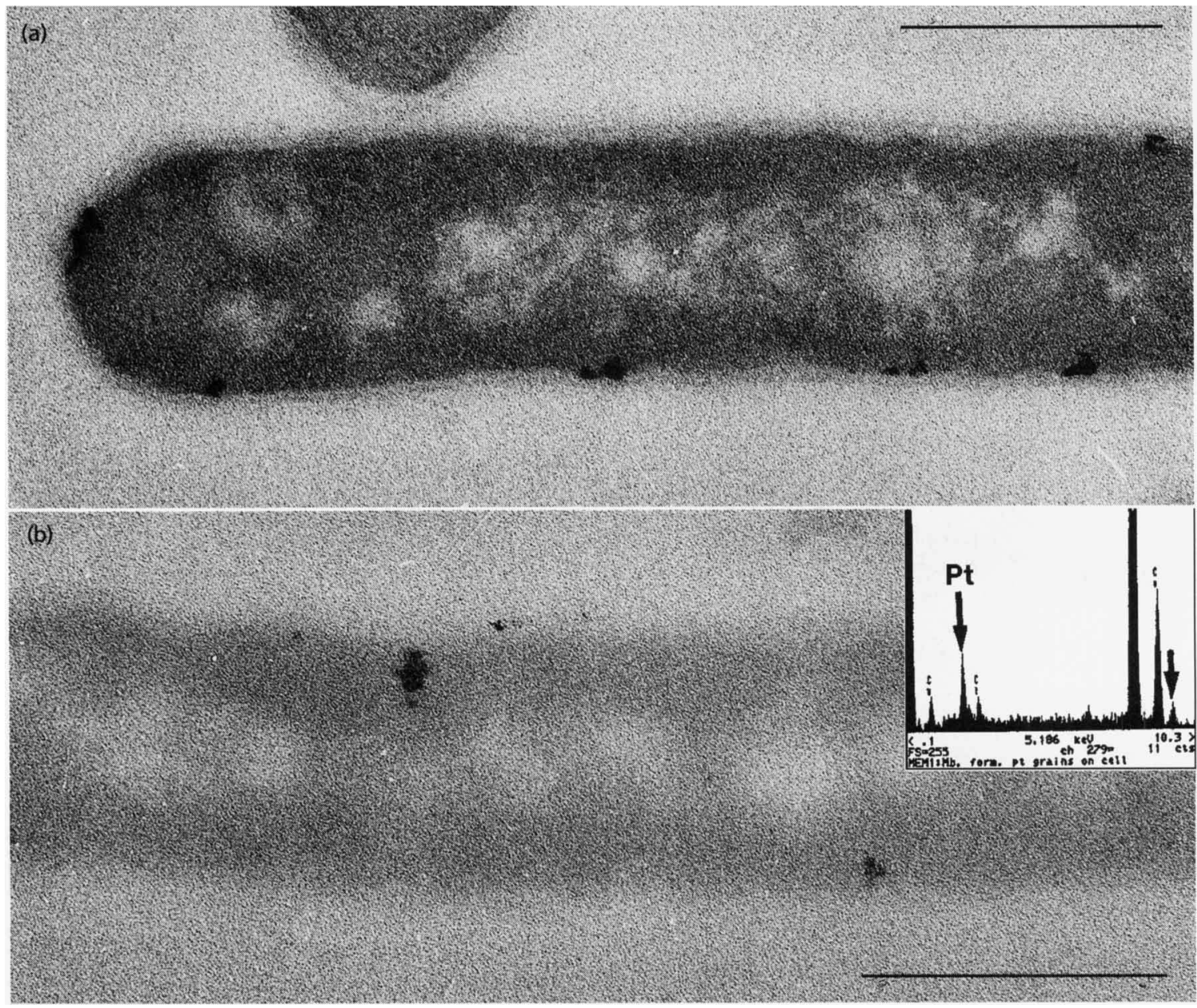

Fig. 4. Heavy-metal-contrasted (a) and uncontrasted (b) thin sections of Methanobacterium formicicum showing the TPtcrystal violet aggregates associated with the cell envelope. An EDS spectrum of the cell in (b) is also shown and confirms the platinum of the TPt in the aggregates (arrows point to the Pt lines in the spectrum). The high copper lines are due to the TEM grid on which the thin section was mounted. Bars, $0.5 \mu \mathrm{m}$.

this case, it seemed that Methanobacterium formicicum's low staining intensity was due to a low retention of crystal violet (as a TPt or iodide complex) as compared to the two Gram-positive eubacterial controls.

The staining of Methanospirillum bungatei was the same as in our former results (Beveridge et al., 1991). The filaments were typically $7-15$ cells long and only the terminal cells stained Gram-positive (see Fig. 3 of Beveridge et al., 1991). The remaining cells in each filament were Gramnegative (Table 1).

\section{Transmission electron microscopy (TEM) and EDS}

TEM was performed at every step of the Gram stain and it was apparent that both the initial crystal violet solution (which contains ethanol) and the ethanol decolorization step were disruptive to the cell envelopes of Sulfolobus acidocaldarius and Methanococcus jannaschii. By the end of the staining regimen, there was not much substance left to the cells (compare Fig. 3a to Fig. 3b and d) and no electrondense TPt deposits could be seen within the bacteria (Fig. 3c), nor could EDS detect TPt (data not shown). Even when Methanococcus jannascbii was grown at $70^{\circ} \mathrm{C}$ to ensure the presence of tetraether lipid, which strengthens and confers rigidity to bilayered membranes (Beveridge $e t$ al., 1993; Choquet et al., 1994), the results were the same (Table 1, Fig. 3d).

Methanobacterium formicicum was not distupted by the staining regimen (Table 1). The cells remained intact and the division sites (septa) were not subject to 'blow-out' as are some Gram-positive eubacteria (Beveridge, 1990). Interestingly, there were few crystal violet-TPt aggregates within the cytoplasm since most were found at the plasma membrane-cell wall interface (Fig. 4a, b). EDS clearly identified the platinum within the aggregates (Fig. 4b). Because these stain aggregates were only found at the cell periphery, the overall number of precipitates was lower than for eubacterial cells (in which the precipitates are spread throughout the cytoplasm; Beveridge \& 


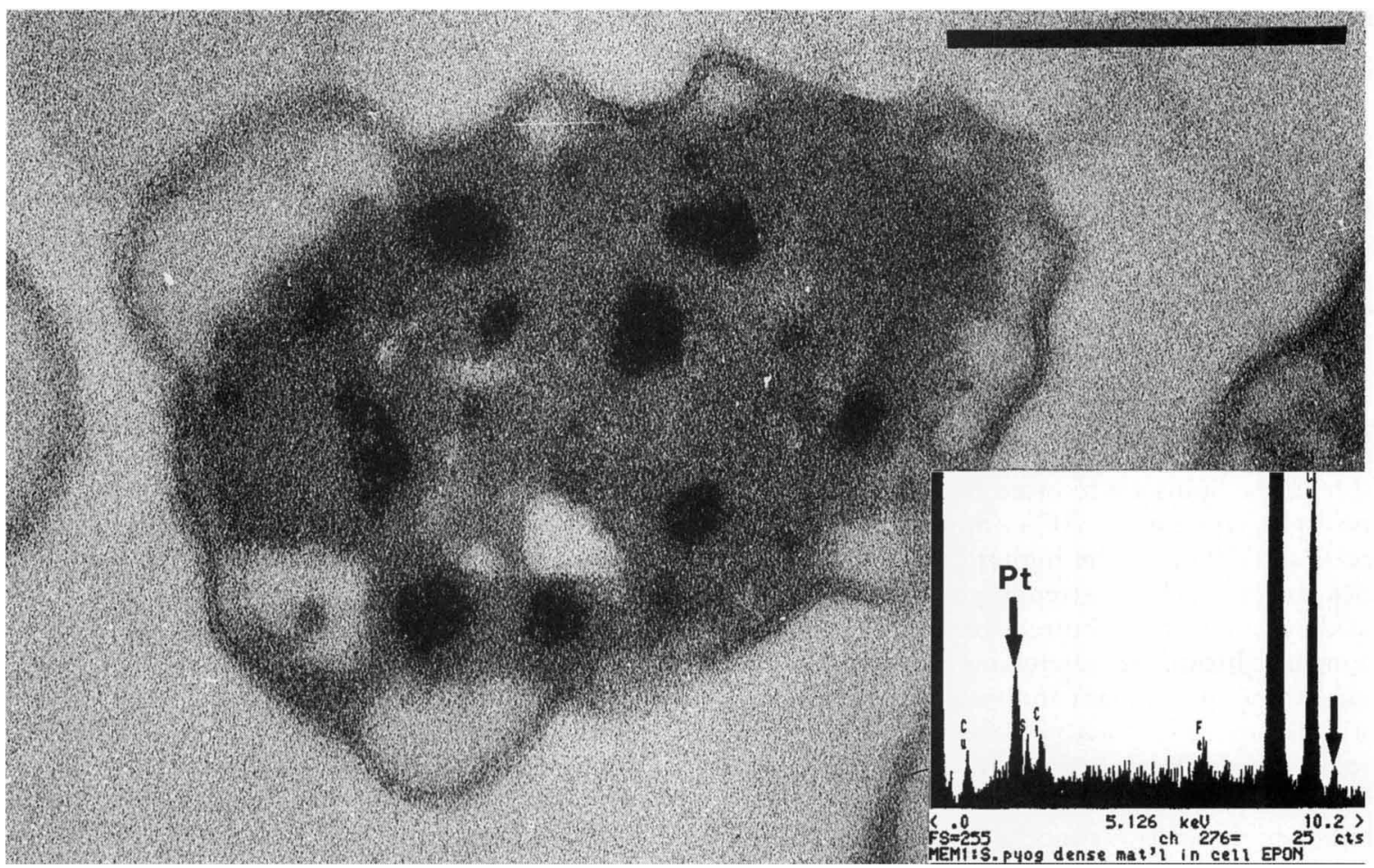

Fig. 5. Heavy-metal-contrasted thin section of a S. pyogenes cell as a Gram-positive eubacterial control. TPt-crystal violet aggregates are spread throughout the cytoplasm, as is confirmed by the EDS spectrum of an unstained cell (arrows point to Pt lines). Bar, $0.5 \mu \mathrm{m}$.

Davies, 1983), and this could account for the lower staining intensity that was seen by LM (Fig. 2b). Presumably, the crystal violet and TPt entered the cell as soluble components and, once in the cytoplasm, reacted together to form a precipitate that was too large to migrate through the cell wall substance and be removed by the decolorization regimen. The precipitates therefore lodged themselves underneath the cell wall. Streptococcus pyogenes (as a Gram-positive eubacterial control) had staining aggregates scattered throughout its cytoplasm (Fig. 5) as did B. subtilis (data not shown). In total per cell, the number of these in the two eubacteria was greater than those found in Methanobacterium formicicum.

We were surprised by the Gram-negative results for Methanosarcina mazei since this archeon is usually considered to be Gram-positive because of its cell envelope structure by TEM and its methanochondroitinous cell wall (Kandler \& König, 1985; Aldrich et al., 1986). This bacterium usually forms large cell aggregates in which the wall of one cell seems continuous with those of neighbouring cells (Sprott \& Beveridge, 1993). Therefore, Methanosarcina mazei usually has robust cell walls which should retain the crystal violet-TPt complex of our Gram stain. At mid-exponential growth phase, our cultures contained cell aggregates of only 4-6 cells; this could be due to the action of the Methanosarcina mazei disaggregatase, which is an enzyme situated at the cell periphery that degrades the cell wall methanochondroitin (Xun et al., 1990; de Macario et al., 1993). The cell walls of our culture were uneven and ranged from 10 to $15 \mathrm{~nm}$ in thickness (Fig. 1d); this unevenness (presumably a result of wall breakdown) made these cells sensitive to the decolorization step of the Gram stain. These bacteria stained Gram-negative because the cells lysed and liberated their crystal violet-TPt aggregates (Table 1).

TEM and EDS confirmed earlier work on Methanospirillum bungatei (Beveridge et al., 1991). TEM revealed that all cells within the filaments were intact and, essentially, unaffected by the Gram stain. However, crystal violet-TPt aggregates could only be seen in the terminal cells of each filament (Table 1; see also Fig. 4 of Beveridge et al., 1991). EDS confirmed the presence of platinum in these terminal cells (Table 1). It seemed that the staining reagents entered only through the terminal plugs (i.e. the spacer plug at the end of each filament; see Beveridge $e t$ al., 1987, for more details of the structure of Methanospirillum bungatei), thereby staining the terminal cells. Once crystal violet-TPt aggregates were formed, they were too large to be washed out through these same plugs by the ethanol decolorization step (see Firtel et al., 1994, for a description of plug organization and subunit periodicity). The more internal cells of each filament did not stain Gram-positive because the S-layered sheath (which is their outermost envelope layer) is so impermeable that the staining reagents could not pass through and enter these cells (Beveridge et al., 1991). To our knowledge this remarkable staining phenomenon has, so far, never been identified in another bacterium. 


\section{DISCUSSION}

All of the archaea that were used in this study possessed cell envelopes very different from those found in eubacteria. Methanococcus jannaschii and Sulfolobus acidocaldarius possess very simple cell walls consisting of a single paracrystalline array, or S-layer, composed of protein (Methanococcus jannascbii) or glycoprotein (Sulfolobus acidocaldarius) (Deatherage et al., 1983; Michel et al., 1980; Sprott \& Beveridge, 1993; Weiss, 1974). Both of these archaea produce plasma membranes with high concentrations of membrane-spanning tetraether lipids when grown at elevated temperature (i.e. $70^{\circ} \mathrm{C}$ ). Methanococcus jannaschii can also be grown at $50^{\circ} \mathrm{C}$ and, at this temperature, these lipids are reduced from $\sim 45 \%$ of the membrane lipid content to $20 \%$ (Sprott et al., 1991; Beveridge et al., 1993). At the higher concentration, the membranes are so greatly strengthened by tetraether lipids that they cannot be fractured through their hydrophobic domains during freeze-etching (Beveridge et al., 1993). Using these two archaea and two growth temperatures for Methanococcus jannaschii, we were able to determine if simple S-layered walls containing either protein or glycoprotein, and plasma membranes containing either high or low concentrations of tetraether lipids, had any effect on the action of the Gram stain. Neither of these archaea could retain enough cell envelope integrity during staining to entrap crystal violet-TPt precipitates at any temperature (Table 1). These bacteria stain Gram-negative because their S-layers and plasma membranes (even with a high tetraether content) are disrupted and dissolved (Fig. 3b, d). Presumably, this is because their S-layers are held together by only weak bonding forces (i.e. ionic bonding and hydrophobic interaction) and their plasma membranes are sensitive to the ethanol of the decolorization regimen of the Gram stain. Additional experiments whereby these cells were subjected to only ethanol $(50-100 \%, \mathrm{v} / \mathrm{v})$ also lysed these cells ( $T$. J. Beveridge, unpublished results). In both these ethanol and Gram-stain experiments, the cellular residue sustained the natural spherical shape of the cells (this is the minimal energy shape of the vesicular remains) and carbol fuchsin ionically bonded to the spheres to stain them red (see Beveridge \& Davies, 1983, for more details).

Methanosarcina mazei and Methanospirillum bungatei also stained Gram-negative but for entirely different reasons. Under our growth conditions Methanosarcina mazei did not develop large clusters of cells with thick cell walls. Instead, the walls were $10-15 \mathrm{~nm}$ thick and aggregates of 4-6 cells were common, presumably because of the hydrolytic action of disaggregatase, an enzyme which is found in the cell envelope and breaks down wall material (Xun et al., 1990; de Marcario et al., 1993). Like the envelopes of Methanococcus jannaschii and Sulfolobus acidocaldarius, those of Methanosarcina mazei could not withstand the action of the Gram stain (Table 1). Laboratory cultures of Methanosarcina mazei which have entered stationary growth phase, or cells in natural microbial communities, typically result in aggregates of 20 or more cells, each with thick $(25-50 \mathrm{~nm})$ robust walls (Sprott \& Beveridge, 1993). Most cells in these aggregates will stain Gram- positive by LM (T. J. Beveridge, unpublished data). It is important to recognize that growth phase, activity of disaggregatase, and cell wall thickness can affect this archeon's response to the Gram stain. Thus, for Metbanosarcina maze $i$, the Gram stain can be an unreliable diagnostic technique.

The most remarkable staining response was seen with Methanospirillum bungatei. Most of the cells of this culture were Gram-negative because the staining reagents were too large to pass through the outermost cell envelope layer, the S-layered sheath, and enter the cytoplasm. Only the terminal cells of each filament stained Gram-positive since the reagents, in this case, could enter through the terminal plugs. These results confirm our earlier report (Beveridge et al., 1991) and we will not reiterate the expanded explanations here. Research has continued to verify the extraordinary physical and chemical resilience of Metbanospirillum hungatei's S-layered sheath. For example, only the most harsh chemical conditions (e.g. extremely high $\mathrm{pH}$ or phenol) are capable of disrupting its fabric (Beveridge et al., 1985; Southam \& Beveridge, 1992) and it can withstand almost $400 \mathrm{~atm}$ of physical pressure (Xu et al., 1996). The sheath's minute pore-size and its strong physical nature are unaffected by the Gram stain and these properties ensure this archeon's unique staining response.

Archaea possess a remarkable variety of cell envelope structural formats and chemical compositions. The present study has shown that in these organisms, as in eubacteria, the Gram stain is dependent on these cell envelopes, especially the cell walls. The physical nature of the wall and, particularly, its bonding structure are of utmost importance. Simple, single S-layered walls (such as those of Methanococcus jannaschii and Sulfolobus acidocaldarius) possess subunits that are weakly bonded to one another (Messner \& Sleytr, 1992) and intimately associated with the underlying plasma membrane; these walls are breached by the action of the Gram stain. More robust walls (such as those of Methanosarcina mazel) can be subject to the lytic action of disaggregatase so that they, too, are disrupted during staining. Highly bonded cell walls (such as those of Methanobacterium formicicum), containing an analogue of peptidoglycan (i.e. pseudomurein), are strong enough to ensure that the cells stain Gram-positive even though the stain distribution differs from that found in Gram-positive eubacteria. Remarkably, at least one archeon (Methanospirillum bungatei) has such an impermeable envelope layer (the sheath) that the staining reagents cannot enter the majority of the cells.

The Gram stain may depend on the cell envelope in archaea, but the exceptional variability of these envelopes between genera ensures that the essential mechanism of Gram reaction can be quite different from that seen in eubacteria.

\section{ACKNOWLEDGEMENTS}

We are especially grateful to G. B. Patel and G. D. Sprott, Institute of Biological Sciences, National Research Council, Ottawa, Canada, for supplying some of the methanogens which 
were used in this study, to A. Winningham, Department of Condensed Matter Physics, University of Colorado, Boulder, CO, USA, for introducing us to Sulfolobus acidocaldarius, and to S. Langley of our laboratory for helping with the S. acidocaldarius experiment. This research was funded by a Medical Research Council grant.

\section{REFERENCES}

Aldrich, H. C., Robinson, R. W. \& Williams, D. S. (1986). Ultra structure of Methanosarcina mazei. Syst Appl Microbiol 7, 314-319.

Beveridge, T. J. (1981). Ultrastructure, chemistry, and function of the bacterial cell wall. Int Rev Cytol 72, 229-317.

Beveridge, T. J. (1988). The bacterial surface: general considerations towards design and function. Can J Microbiol 34, 363-372.

Beveridge, T. J. (1990). Mechanism of Gram variability in select bacteria. J Bacteriol 172, 1609-1620.

Beveridge, T. J. \& Davies, J. A. (1983). Cellular response of Bacillus subtilis and Escherichia coli to the Gram stain. J Bacteriol 156, 846-858.

Beveridge, T. J. \& Graham, L. L. (1991). Surface layers of bacteria. Microbiol Rev 55, 684-705.

Beveridge, T. J., Stewart, M., Doyle, R. J. \& Sprott, G. D. (1985). Unusual stability of the Methanospirillum bungatei sheath. $J$ Bacteriol $162,728-737$.

Beveridge, T. J., Harris, B. J. \& Sprott, G. D. (1987). Septation and filament splitting in Methanospirillum bungatei. Can. J Microbiol 33, 725-732.

Beveridge, T. J., Sprott, G. D. \& Whippey, P. (1991). Ultrastructure, inferred porosity, and Gram staining character of Methanospirillum bungatei filament termini describe a unique cell permeability for this archaeobacterium. J Bacteriol 173, 130-140.

Beveridge, T. J., Choquet, C. C., Patel, G. B. \& Sprott, G. D. (1993). Freeze-fracture planes in methanogen membranes correlate with the content of tetraether lipids. J Bacteriol 175, 1191-1197.

Breuil, C. \& Patel, G. B. (1980). Composition of Methanospirillum bungatei GP1 during growth on different media. Can J Microbiol 26, $577-582$.

Brock, T. D., Brock, K. M., Belly, R. T. \& Weiss, R. L. (1972). Sulfolobus: a new genus of sulfur-oxidizing bacteria living at low $\mathrm{pH}$ and high temperature. Arch Mikrobiol 84, 54-68.

Chock, P. B., Halpern, J. \& Paulik, F. E. (1973). Potassium trichloro(ethylene)platinate(II) (Zeisse's salt). Inorg Synth 14, 90-92.

Choquet, C. G., Patel, G. B., Beveridge, T. J. \& Sprott, G. D. (1994) Stability of pressure-extruded liposomes made from archaeobacterial ether lipids. Appl Microbiol Biotechnol 41, 375-384.

Davies, J. A., Anderson, G. K., Beveridge, T. J. \& Clark, H. C. (1983). Chemical mechanism of the Gram stain and synthesis of a new electron-opaque marker for electron microscopy which replaces the mordant of the stain. $J$ Bacteriol 156, 837-845.

Deatherage, J. F., Taylor, K. A. \& Amos, L. A. (1983). Threedimensional arrangement of cell wall protein of Sulfolobus acidocaldarius. J Mol Biol 167, 823-852.

Ferrante, G., Richards, J. C. \& Sprott, G. D. (1990). Structures of polar lipids from the thermophilic deep-sea archaeobacterium Methanococcus jannaschii. Biochem Cell Biol 68, 274-283.
Firtel, M., Southam, G., Harauz, G. \& Beveridge, T. J. (1993). Characterization of the cell wall of the sheathed methanogen Methanospirillum bungatei GP1 as an S Layer. I Bacteriol 23, 7550-7560.

Firtel, M., Southam, G., Harauz, G. \& Beveridge, T. J. (1994). The organization of the paracrystalline multilayered spacer plugs of Methanospirillum bungatei. I Structural Biol 112, 160-171.

Graham, L. L. \& Beveridge, T. J. (1994). Structural differentiation of the Bacillus subtilis cell wall. J Bacteriol 176, 1413-1421.

Kandler, O. \& König, H. (1985). Cell envelopes of archaebacteria. In The Bacteria, vol. VIIl, pp. 413-457. Edited by C. R. Woese \& R. S. Wolfe. New York: Academic Press.

König, H. (1988). Archaeobacterial cell envelopes. Can J Microbiol 34, 395-406.

Langworthy, T. A. (1985). Lipids of archaebacteria. In The Bacteria, vol. VIII, pp. 459-497. Edited by C. R. Woese \& R. S. Wolfe. New York: Academic Press.

de Macario, E. C., Macario, A. J. L., Mok, T. \& Beveridge, T. J. (1993). Immunochemistry and localization of the enzyme disaggregatase in Methanosarcina mazei. J Bacteriol 175, 3115-3120.

May, H. D., Patel, P. S. \& Ferry, J. G. (1988). Effect of Molybdenum and tungsten on synthesis and composition of formate dehydrogenase in Methanobacterium formicicum. J Bacteriol 170, 3384-3389.

Messner, P. \& Sleytr, U. B. (1992). Crystalline bacterial surface layers. Adv Microb Physiol 33, 213-275.

Michel, H., Neugebauer, D.-C. \& Oesterheld, D. (1980). The 2-d crystalline cell wall of Sulfolobus acidocaldarius: structure, solubilization, and reassembly. In Electron Microscopy at Molecular Dimensions, pp. 27--35. Edited by W. Baumeister \& W. Vogell. Berlin \& New York: Springer-Verlag.

Sprott, G. D. \& Beveridge, T. J. (1993). Microscopy. In Methanogenesis: Ecology, Physiology, Biochemistry and Genetics, pp. 81-127. Edited by J. G. Ferry. New York: Chapman \& Hall.

Sprott, G. D., Shaw, K. M. \& Jarrell, K. F. (1983). Isolation and chemical composition of the cytoplasmic membrane of the archaebacterium Methanospirillum bungatei. J Biol Chem 258, 4026-4031.

Sprott, G. D., Meloche, M. \& Richards, J. C. (1991). Proportions of diether, macrocyclic diether and tetraether lipids in Methanococcus jannaschii grown at different temperatures. J Bacteriol 173, 39073910.

Southam, G. \& Beveridge, T. J. (1992). Characterization of a novel, phenol-soluble group of polypeptides which convey rigidity to the sheath of Methanospirillum bungatei GP1.J Bacteriol 174, 935-946.

Stewart, M., Beveridge, T. J. \& Sprott, G. D. (1985). Crystalline order to high resolution in the sheath of Methanospirillum bungatei: a cross-beta structure. J Mol Biol 183, 509-515.

Weiss, L. R. (1974). Subunit cell wall of Sulfolobus acidocaldarius. J Bacteriol 118, 275-284.

Xu, W., Mulhern, P. J., Blackford, B. L., Jericho, M. H. \& Beveridge, T. J. (1996). Modelling and measuring the elastic properties of an archaeal surface, the sheath of Methanospirillum bungatei, and the implication for methane production. J Bacteriol 178, 3106-3112.

Xun, L., Mah, R. A. \& Boone, D. R. (1990). Isolation and characterization of disaggregatase from Methanosarcina mazei LYC. Appl Environ Microbiol 56, 3693-3698.

Received 13 February 1996; revised 24 May 1996; accepted 30 May 1996. 